\title{
Who Cares? Welfare and Consent to Child Emigration from England to Canada, 1870-1918
}

DOI:

10.1007/s10991-019-09234-y

Document Version

Accepted author manuscript

Link to publication record in Manchester Research Explorer

\section{Citation for published version (APA):}

Lamont, R., Moss, E., \& Wildman - Tarozzi, C. (2019). Who Cares? Welfare and Consent to Child Emigration from England to Canada, 1870-1918. Liverpool Law Review. https://doi.org/10.1007/s10991-019-09234-y

\section{Published in:}

Liverpool Law Review

\section{Citing this paper}

Please note that where the full-text provided on Manchester Research Explorer is the Author Accepted Manuscript or Proof version this may differ from the final Published version. If citing, it is advised that you check and use the publisher's definitive version.

\section{General rights}

Copyright and moral rights for the publications made accessible in the Research Explorer are retained by the authors and/or other copyright owners and it is a condition of accessing publications that users recognise and abide by the legal requirements associated with these rights.

\section{Takedown policy}

If you believe that this document breaches copyright please refer to the University of Manchester's Takedown Procedures [http://man.ac.uk/04Y6Bo] or contact uml.scholarlycommunications@manchester.ac.uk providing relevant details, so we can investigate your claim.

\section{OPEN ACCESS}




\section{Liverpool Law Review \\ Who Cares? Welfare and Consent to Child Emigration from England to Canada, 1870- 1918 \\ --Manuscript Draft--}

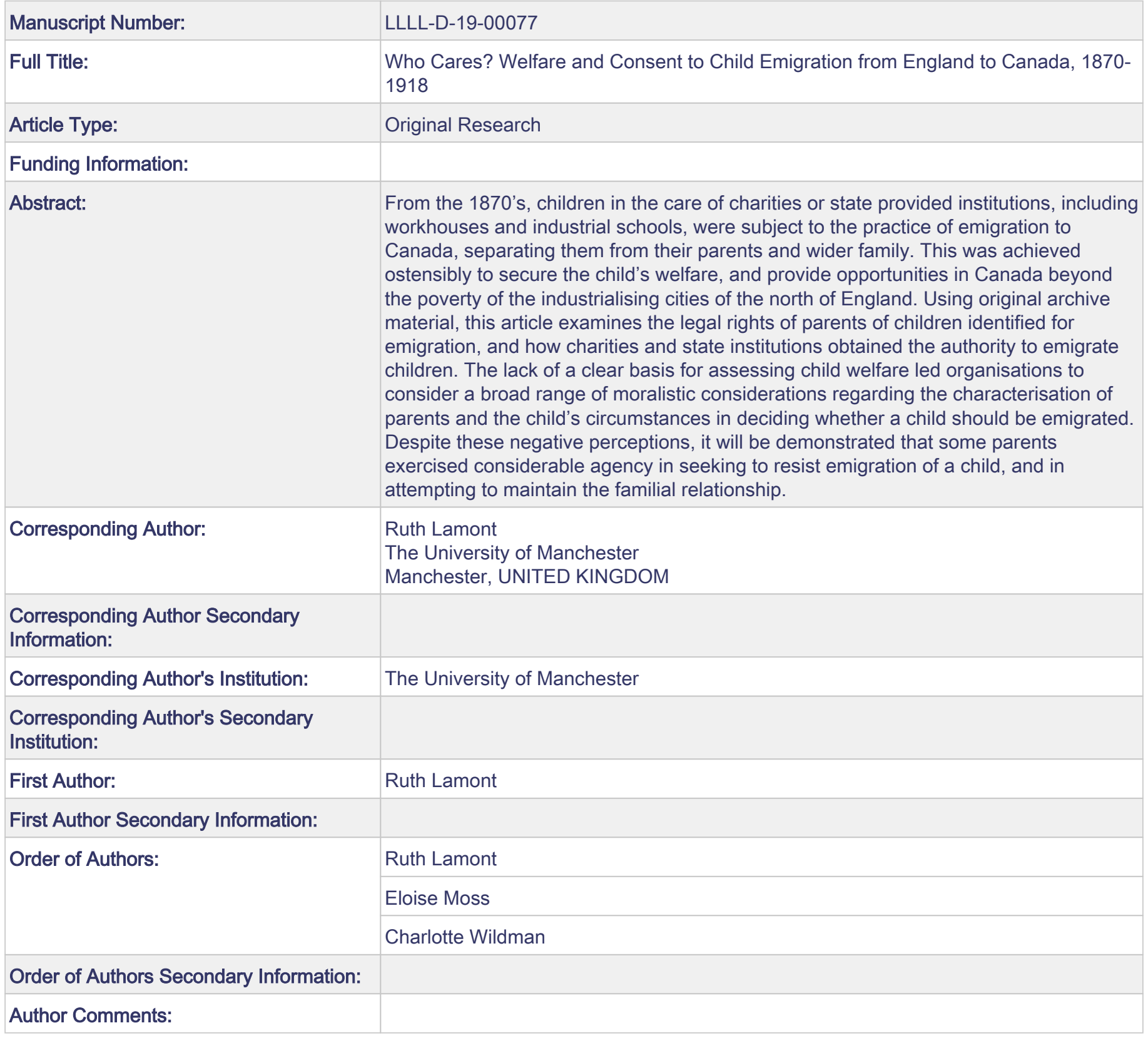


Who Cares? Welfare and Consent to Child Emigration from England to Canada, 1870-1918

Ruth Lamont, Senior Lecturer in Family and Child Law, University of Manchester (correspondence author: ruth.lamont@ manchester.ac.uk) ORCID: 0000-0002-9025-8771

Eloise Moss, Lecturer in Modern British History, University of Manchester ORCID: 00000003-0332-0045

Charlotte Wildman, Senior Lecturer in Modern British History, University of Manchester ORCID: 0000-0002-1131-0720

On behalf of all authors, the corresponding author states that there is no conflict of interest.

\section{Acknowledgements}

We are grateful to Philp Handler and Carolyn Abbot for their comments on earlier drafts. The archival research forming the basis of this article was supported by funding from the H-SIF fund, University of Manchester. 


\title{
Who Cares? Welfare and Consent to Child Emigration from England to
} Canada, 1870-1918

\begin{abstract}
From the 1870's, children in the care of charities or state provided institutions, including workhouses and industrial schools, were subject to the practice of emigration to Canada, separating them from their parents and wider family. This was achieved ostensibly to secure the child's welfare, and provide opportunities in Canada beyond the poverty of the industrialising cities of the north of England. Using original archive material, this article examines the legal rights of parents of children identified for emigration, and how charities and state institutions obtained the authority to emigrate children. The lack of a clear basis for assessing child welfare led organisations to consider a broad range of moralistic considerations regarding the characterisation of parents and the child's circumstances in deciding whether a child should be emigrated. Despite these negative perceptions, it will be demonstrated that some parents exercised considerable agency in seeking to resist emigration of a child, and in attempting to maintain the familial relationship.
\end{abstract}

\section{Keywords}

Child emigration; child protection; welfare; legal history; child law

\section{Introduction}

Between 1870 and 1918 an estimated 80,000 children were emigrated from the UK to Canada to begin lives as adoptees of, or working within, Canadian families. ${ }^{1}$

Emigration was carried out by voluntary religious and charitable organisations aiming to secure the welfare of vulnerable children given their personal circumstances. These charities provided a range of support to children who were deemed without family, or had passed into an institution because their family could not maintain them, or was regarded as harmful to them. Emigration was regarded as a desirable outcome for these children, detaching them from perceived risks at home and providing a job and training, supporting the employment needs of a growing Canadian economy and, by extension, the British empire. ${ }^{2}$ Early promotional literature seeking financial support for these charitable ventures argued: '...we do not want these beggar girls of London, of our big cities,... who will be so good or so bad according to the circumstances surrounding their young and building-up years, and...our beautiful, thrifty, kindly Canada,...she wants them, will take them, mother them, save them. ${ }^{3}$

The process of emigrating children was begun in England in the 1870s by individuals and localised charities. The state sought to use the structures created by these organisations to emigrate children from workhouses under the poor law, and after

\footnotetext{
${ }^{1}$ Parr (1994).

${ }^{2}$ Boucher (2014).

${ }^{3}$ Miss Rye's Emigration Home for Destitute Little Girls, Annual Report 1878, Liverpool University, d630-1-1-17.
} 
1891, from industrial schools ${ }^{4}$ that had been established to provide work and housing for children who had been abused, orphaned or found vagrant. This process of intervention and assertion of control over vulnerable children intended to secure their welfare marks the beginning of the modern system of child protection through the permanent removal of children from parental care. ${ }^{5}$ This article will examine the judgments made of parental care and the highly significant perceptions of child welfare that determined the future for the individual child.

In the late nineteenth century both state and charitable institutions were increasingly empowered by law to act on behalf of children. Children placed with a charity or in workhouses were identified as 'friendless', 'belonging to nobody', deserted or orphaned, even if they still had relationships with close family. The assertion of authority over parental care judged to be inadequate by these institutions eventually entailed legal denial of the parents' right to consent to the child's emigration. This paper examines this process and the legal regulation and protection of parental rights within which lie the origins of modern child protection measures. Emigration was designed to permanently sever familial relationships and parental control over the treatment of their children. Whilst the consent of the child to emigration was still sought in some circumstances, parental or guardian consent was formally dispensed with. This denial of consent was central to the disempowerment of parents in the interests of securing what was perceived as the child's welfare, even if the family demonstrated a desire to maintain a relationship with the child, or merely had not the means and resources to maintain them. ${ }^{6}$

Through examination of the archival records of emigration from institutions in Manchester and Liverpool, this paper will argue that the lack of a clear basis for assessing child welfare led to a broad range of moralistic considerations adopted by charitable organisations in identifying whether a child should be emigrated. The analysis of a range of archive material associated with charitable activities, including promotional publications, records of children emigrated and correspondence, is highly significant in demonstrating the anxieties surrounding parenting and the well-being of poor children. Using this original evidence, it will be suggested that state and charitable institutions sought to avoid parental engagement and presented decisionmaking regarding emigration of children to the wider public and state institutions as a decision securing the child's welfare and future. Yet, in the face of perceived negative environment and parenting, some families sought to prevent the emigration of their children and deployed several strategies to challenge these damaging perceptions.

Part I will explore the regulation of child emigration and the routes into emigration from charitable institutions, through the poor law workhouses, and from industrial schools. The circumstances in which the child may be identified for emigration was different in each institutional context, but erosion of parental consent to emigration

\footnotetext{
${ }^{4}$ s.1, Reformatory and Industrial Schools Act 1891.

${ }^{5}$ Eekelaar et al (1982).

${ }^{6}$ Eekelaar (1994).
} 
once the child was placed within an institution is a clear legal strategy. Part II will examine in more detail the archival records to identify the moralistic nature of decision-making in relation to children and the anxieties surrounding parental influence on children. The strategies exceptionally adopted by families to resist or challenge emigration will be considered to demonstrate the interest of families in their children, and the challenge they posed to the perception of poor parenting and lack of care.

\section{Child Welfare and Emigration: Removing Parental Consent}

By the late nineteenth century, emigration was part of the psychological mindset of the British population. ${ }^{7}$ Most emigration was achieved without state assistance and the process was unplanned by state authority until the mid-twentieth century. ${ }^{8}$ Emigration could provide economic benefit and opportunity for social advancement and was an important aspect of Empire building, securing the links between the colony and the so-called 'Mother Country'. Eric Richards argues that emigration was identified '... as an all-purpose solution to British social problems-diminishing its excessive convict populations, its poor, its surplus women, its unemployed, its crime, its difficult sons and other relatives. "' Securing the welfare of neglected, criminal or orphaned children in industrial cities was one purpose to which emigration was put from the mid-nineteenth century. This section explores the legal and practice frameworks surrounding emigration from charitable homes, the workhouse and industrial schools. The parental role of caring for, and holding authority over, their child as previously understood was increasingly regulated and marginalised as the process of emigration and settlement in Canada was promoted as particularly desirable for deprived children.

The emigration of children was built on the perception that the opportunities provided for secure work, particularly agricultural labour, would be of great benefit both to the child, but also to the development of the colony. Emigrating agencies' marketing and fundraising materials emphasised the desirability of the colonial life in contrast to the marginal, insecure and neglectful lives experienced by many children. The annual report of Father Berry's Homes for Destitute Boys in 1895 stated:

'Criminals are made upon our streets, and every man who takes away one street trading boy from his surroundings of temptation does a good work in reclaiming the boy and in saving the expenses which are likely to be incurred by his more than probable transmission to workhouse or to gaol. ${ }^{10}$

No clear distinction was drawn between neglected and delinquent children since juvenile offending was attributed to neglectful parenting. ${ }^{11}$ As the report stressed, the removal of children, particularly from urban settings, was central to interrupting the

\footnotetext{
${ }^{7}$ Richards (2004).

${ }^{8}$ Empire Settlement Act 1922.

${ }^{9}$ Richards (2004).

${ }^{10}$ Father Berry’s Homes 1892-1904, Liverpool Hope University.

${ }^{11}$ Dingwell, R, et al (1984).
} 
journey of miscreant children towards criminality, as well as offering a frugal alternative to other forms of welfare.

\section{Charitable Organisation of Child Emigration}

From its inception, the stated purpose of emigration by philanthropic organisations was to prevent the apparent risks of criminality and destitution posed to children in the industrialised cities. Father James Nugent, one of the founders of the child emigration system, sought to create Catholic homes and to emigrate children from Liverpool in an attempt to address what he regarded as a significant social problem:

'Already evil in its twofold form of vice and sorrow blocks their pathway in life, to corrupt and afflict them. What an existence, what an education, what a future! The streets are the schools of crime. Twenty five thousand in Liverpool and a proportionate number in Manchester, Birmingham, Leeds and the other large towns of England. ${ }^{12}$

Emigration of children was pursued as being beneficial to the individual child, removing them from poverty and under-employment within the industrial cities of London and in the north of England. Emigration provided opportunities for employment on the land, security for the child's religious faith, and undermined the risks of exposure to immorality and criminality in the 'land of plenty'. ${ }^{13}$ Children from throughout Britain, but particularly the industrial cities of London, Manchester, Liverpool, Glasgow and Birmingham, were emigrated to base homes in Canada. From there, they were placed with families, either explicitly employed as a cheap form of agricultural or domestic labour, or informally adopted by the family. ${ }^{14}$ Canada was not a significant destination for colonial migration until the 1870 s since most emigrants sought to make their way to the United States. However, increasing demand for agricultural and servant labour to support the developing Canadian economy encouraged the activities of the early child emigration philanthropists to secure emigrants from the UK to various provinces. This was eventually followed by a large range of charities across the country, including Dr Barnardo's in London from 1889, forging a complex range of localised and religious institutions. Liverpool and Manchester formed hubs of emigration activity because of acute deprivation and large numbers of destitute children evident within the city environment, particularly following the influx of Irish immigrants following the Famine. Local patterns of deprivation influenced enthusiasm for emigration, and the desire to protect the Catholic faith of children was a particular focus of Father Nugent's activities.

These organisations were highly active in trying to secure financial subscriptions supporting the establishment of institutional homes and training for children in England, and fundraising for the costs of emigration, including clothing and initial housing for the children on arrival in Canada. The opportunities provided in Canada were a central aspect of reports on the charities' activities and the calls for more

\footnotetext{
${ }^{12}$ Fr James Nugent Personal Notes vol.1 Liverpool Hope University.

${ }^{13}$ Moss (2017).

${ }^{14}$ Parker (2008).
} 
subscriptions. In 1882, the Report of Miss Rye's Emigration Home told subscribers that the Committee: '...feel the very urgent need for more effort on the part of all, ...to enable them if possible to remove from their present dangerous surroundings to a land where they may "eat bread without scarceness", 15

In many cases, parent(s) placed their child in a charity home because they could not effectively provide for them. For example, in November 1900, AH, aged 10, was placed with the Manchester and Salford Boys' and Girls' Refuges and Children's Aid Society by his mother who '... appears to be ill suffering from bronchitis \& rheumatism. She says she has no friends and has battled on as long as she could.' The mother's statement as to her circumstances was supported by additional testimony by her former employer who described the mother and boy as 'half starved' ${ }^{16}$

Whilst the child's parent was still living they retained parental rights over their child, enabling them to refuse or consent to the child's emigration, even when the child was placed in the care of a charitable children's home. However, Barnardo's charity wantonly ignored this obligation in seeking to secure the emigration of a child where their parents were regarded as a malign influence and was reported to have appeared in court over 80 times in cases where appropriate consent had not been secured. ${ }^{17}$ Barnardo was blatant in breaching the law, stating in the charity's magazine, Night and Day, that '...in no fewer than forty-seven well marked cases I have myself done that which the law of the land would neither do for me, nor knowingly permit me to do - i.e. ABDUCTED CHILDREN IN ORDER TO SAVE THEM'. ${ }^{18} \mathrm{He}$ argues that the parent of the child should be deprived of that status upon representation to the magistrate that they were: '...habitual drunkards, who are known to pursue immorality as a livelihood, who are vicious or criminal, or who subject their children to influences which must certainly result in these children becoming criminal or immoral....' 19

Despite Barnardo's confidence in his moral right to deny the parents access to and control over their children, the courts were not convinced of his legal right to do so. In Gossage's Case a writ of habeas corpus was issued for the return of Henry Gossage, aged 12, despite Barnardo's argument that it was now impossible to locate the child in Canada. ${ }^{20}$ Subsequently, in $R v$ Barnard $o^{21}$ Martha Ann Tighe, aged 13, had passed into the care of a Barnardo's Home for Destitute Children in Bristol and subsequently transferred to London. Martha's mother had married again and demanded the return of her daughter from London but, despite receiving the mother's letter, Dr Barnardo

\footnotetext{
${ }^{15}$ Report of 1882 of Miss Rye's Emigration Home for Destitute Little Girls, University of Liverpool d630-1-1-17.

${ }^{16}$ Manchester and Salford Boys' and Girls' Refuges and Children's Aid Society, Admissions Files.

Together Trust.

${ }^{17}$ Eekelaar (1994).

${ }^{18}$ Barnardo (1885).

${ }^{19}$ Ibid.

20 (1890) 24 QBD 283.

${ }^{21}$ (1889) 23 QBD 305.
} 
had given Martha into the care of a woman to emigrate her to Canada. ${ }^{22}$ A writ of habeas corpus was sought by Martha's mother, but the child was not returned to England. The Court found that Dr Barnardo's attempts to return the child by writing letters were insufficient; he should have made every possible effort to get the child back, including going abroad if necessary. ${ }^{23}$

In Barnardo v McHugh, ${ }^{24}$ Jon Roddy Jones, the illegitimate son of Margaret McHugh, had been baptised a Catholic in 1880, and then as a Protestant in 1884. He had been left to the care of a Barnardo's Home for Destitute Children by the mother who on admission had signed an agreement to leave him in the home for 12 years. This agreement also stated that she could not remove her son from the home without consent of the managers before this date. She requested his return to her care in 1890, which was refused. The court found that anxiety surrounding the perceived risk to the child's Protestant faith by returning to his mother was the reason for the refusal. It was argued that, as the child was illegitimate, the mother had no right of custody over her child which she could enforce for his return. The House of Lords held that she did hold rights of custody over the child until he was 16 , since she was obliged to maintain him. She had a natural right to her son's guardianship, having done nothing effective to deprive herself of them, and there being no evidence that returning the child to her would cause him any injury. The Lord Chancellor, Lord Halsbury, held that the question was one of rightful guardianship, not unlawful detention, and that the agreement the mother had signed did not determine this issue. ${ }^{25}$ The Morning Post commented that: '...any agreement by the parent to abandon control will be treated as contrary to the policy of the law, and therefore voidable. ${ }^{26}$ This judgment enforced the rights of the parent to the custody of their child and the assetion of their authority even where the child had been placed in the care of a charity.

As a consequence, the Custody of Children Act 1891 was passed ${ }^{27}$ with the intention of addressing this lacuna in the power of charities taking on the care of children from their parents. Section 3 provided that the court could refuse delivery of the child where a parent had abandoned or deserted their child, or allowed their child to be brought up by the poor law guardians, for a period of time that satisfied the court that the parent was unmindful of their duties. Unless the parent convinced the court that, having regard to their child's welfare, they were a fit person to have custody of the child, they could not retrieve their child without the permission of the organisation they were placed with. ${ }^{28}$

\footnotetext{
22 'Dr. Barnardo and a Worcester Child. Decision of the Court', Barrow's Worcester Journal 20 July 1889. 
This provision effectively shielded both the poor law guardians and the charitable organisations with the care of children from further writs requiring the return of children either still in England or once emigrated. The central aspect of s.3 was whether the child could be deemed 'abandoned' for a period of time that meant the parent could be deemed 'unmindful' of parental duties. These were subjective matters, and it meant that the return of the child was at the discretion of the court if the parent chose to dispute with the charity they had been placed with. Effectively, once a child was committed to an institution or home for their care, the institution held the authority to control the parents' access and retrieval of their child. The standard for deeming a parent 'unmindful' subsequently became much higher, ${ }^{29}$ but the emphasis was on the parent to prove their interest in the child. The court also retained equitable jurisdiction to determine the relationship between a child and a stranger, suspending the natural guardianship of the parent if '...either the conduct of the parent, or the description of the person he is, or the position in which he is placed, is such as to render it ...clearly right for the welfare of the child in some very serious and important respect that the parent's rights should be suspended or superseded... ${ }^{30}$ In addition, s.6(5), Prevention of Cruelty to Children Act 1894 enabled the Secretary of State to authorise the emigration of a child where their parent or guardian had been convicted of cruelty towards them. This power was subsequently embodied in s.21(6), Children Act 1908 which also provided for the placement of a child where the person having care of them had been charged with cruelty. Children in these circumstances were often placed in charitable children's homes, rather than with extended family. Their parent had been convicted of cruelty towards their child and the child put in the care of another, denying the parent rights over the further care of the child. These provisions enabled the Secretary of State to empower the person or, more frequently the institution, having subsequent care of the child to procure their emigration.

Within this legal framework, charities began to be overt regarding the limitations on parental obligations, including giving notice that the child might be emigrated in the documentation associated with the child's admission. On his admission to the Manchester and Salford Boys' and Girls' Refuges and Children's Aid Society, AH's mother signed a pre-format terms and conditions stating: 'That the Committee may place my son in a home or in a situation or employment, either in England or abroad as the Committee may think proper, without obtaining any further approval or consent from me'. ${ }^{31}$ AH emigrated to Canada in $1909 .{ }^{32}$

\section{Child Emigration and the Poor Law}

Section 62 of the 1834 Poor Law Amendment Act $^{33}$ authorised the use of the rates imposed on parishioners for maintenance of the poor in the parish to instead defray the expense of emigrating poor persons abroad. Emigration was advocated as a means

\footnotetext{
${ }^{29}$ See In Re Thain (An Infant) [1926] Ch. 676.

${ }^{30}$ The Queen v Gyngall [1893] 2 QB 232, 242.

${ }^{31}$ Manchester and Salford Boys' and Girls' Refuges and Children's Aid Society, Admissions Files.

${ }^{32}$ Ibid.

${ }^{33} 4$ \& 5 Will 4 c. 76.
} 
of reducing the reliance on the poor rates through a process of encouraging relocation to the colonies, simultaneously contributing to the settlement of new land within the Empire: '...men will be astonished to find what small modicum of relief, in the way of emigration, will answer every good purpose, and restore our rural population to a healthy state. ${ }^{34}$ Practices differed between Unions, but Howells' study of the Norfolk Union has demonstrated that assisted emigration was made available to families of labourers with the emphasis on emigration of entire families, rather than of individual children, during periods of rural distress. ${ }^{35}$ It was closely controlled and regulated to limit assisted emigration to 'deserving families'. ${ }^{36}$ The representation of healthy positive outcome for the poor in taking advantage of emigration established a narrative arguing for reduced pressure on local poor rates whilst extolling the virtues of emigration to the Empire and value of labour in the colonies.

From the 1870's, children, rather than entire families, were recruited for emigration from the poor law authorities by charitable emigration organisations. The Poor Law Amendment Act $1850^{37}$ authorised the parish guardians to expend money on the emigration of any poor orphan or deserted child under 16 having no settlement (a link with a particular parish), with the consent of the child before the Justices, and the agreement of the Poor Law Board. Whilst this provision enabled the emigration of children outside the family structure, it was a circumscribed power. Although it was possible to characterise a child as orphaned or deserted and children were often labelled as 'orphaned' if they were separated from their parents, ${ }^{38}$ eligibility relied on the child having no settlement. In these circumstances, no element of parental consent was required because the parent was absent, dead or had abandoned the child.

In 1889, an additional amendment provided that if the parents deserted their child, the parish guardians could pass a resolution assuming all the rights and powers of a parent over the child. ${ }^{39}$ This provision was identified as the forerunner of modern child protection legislation by the House of Lords in Re M and H (Minors) (Local Authority: Parental Rights $)^{40}$ because it enabled the guardians by resolution to assume all parental rights and powers, subject to challenge by the parent or guardian. Frost argues that from this period onwards guardians increasingly perceived their role as 'rescuing' children from physical or moral danger and that securing children's welfare was, for some poor law unions, more important than saving funds. ${ }^{41}$ One way of

\footnotetext{
${ }^{34}$ William Fergusson 'Thoughts and observations upon pauperism, poor laws, emigration, medical relief and the prevention of crime' 1839 . Hume Tracts. The value of emigration for the poor was not completely accepted, with anxiety expressed that emigration would tend to increase reliance on the rates, leaving only the disabled and indigent see for example, George Strickland 'Discourse on the Poor Laws on England and Scotland, on the state of the poor in Ireland, and on emigration' $2^{\text {nd }}$ edition 1830.

${ }^{35}$ Howells (2000).

${ }^{36}$ Haines (1997).

${ }^{37}$ s.3, Poor Law Amendment Act 1850.

${ }^{38}$ Parker (2008).

${ }^{39}$ s. 1, Poor Law Act 1889.

40 [1990] 1 AC 686, 705.

${ }^{41}$ Frost (2013)., G. 'Under the Guardian's Supervision: Illegitimacy, Family and the English Poor Law 1870-1930' (2013) 38 Journal of Family History 122, 134. This was not universally the case since some unions, such as Liverpool, did not have the resources to engage directly in rescuing activities.
} 
securing the child's welfare was to pay a charitable organisation to emigrate the child

\footnotetext{
${ }^{42}$ Eekelaar (1994).

${ }^{43}$ Doyle Report (1875).

${ }^{44}$ A small number of children were still emigrated to Canada despite the moratorium, see Parker (2008).

45 'Question of Child Emigration: Chorlton Guardians Differ', Manchester Courier and Lancashire General Advertiser, $7^{\text {th }}$ March 1908.

${ }^{46}$ See Godfrey (2017).

${ }^{47}$ This Act had its origins in An Act to make Better Provision for the Care and Education of Vagrant, Destitute, and Disorderly Children and for the Extension of Industrial Schools, 20 \& 21 Vict. c 48. ${ }^{48}$ ss.VI-VII, Industrial Schools Act 1857. Under s.XII, the parent could remove the child from the school if evidence was provided of employment for life, or other sufficient reason.

49 This was expanded to include refractory children under the care of the guardians, and children whose parent(s) had been convicted of a felony and imprisoned, s.17, Industrial Schools Act 1866.
} 
criminal offence could be sent to an industrial school rather than being imprisoned or committed to a reformatory. ${ }^{50}$

From 1891, the managers of industrial schools were empowered, with the child's consent and the agreement of the Secretary of State, to provide for the emigration of a well-conducted child. ${ }^{51}$ There was no provision in the legislation for the consent, or even consultation, of parents by school managers prior to emigration. The circumstances in which a child could be committed to an industrial school were again clarified by the Children Act $1908^{52}$ which also maintained the power to emigrate children under s.70:

'If any...child detained in ... a certified school...conducts himself well, the managers of the school may, with his own consent...dispose of him...by emigration,... and such disposition shall be as valid as if the managers were his parents. Provided that where he is to be disposed of by emigration...the consent of the Secretary of State shall also be required.'

The Aberdare Royal Commission in 1882 found that emigration was regarded by industrial schools as the surest way of separating the child from pernicious parental influence, but was expensive, and no additional funds were forthcoming from the Treasury to facilitate it. ${ }^{53}$ Parker notes that the requirement to secure the permission of the Secretary of State restricted the extent to which children emigrated from either industrial or reformatory schools. ${ }^{54}$

Children deemed suitable for emigration were usually transferred through the services of the emigration charities, which often had a close link with industrial and reformatory schools, frequently running them alongside children's homes. The Form of Application for Emigration of a Child for the Liverpool Catholic Children's Aid Committee, used from 1900, required extensive details from the charity or institution applying for emigration. Whilst it recorded details about the parents: whether living or dead, their nearest relative and address, the signature of current guardian was the only requirement. If a child was to be emigrated from an industrial school, the reason for committal to the industrial school had to be declared and 'greatest care must be taken in selecting industrial school cases for emigration'. ${ }^{55}$

By 1917, the Royal Commission on the Dominions argued that there should be more activity in emigrating children to Canada since demand exceeded supply and the

\footnotetext{
${ }^{50}$ Reformatory schools were designed for children convicted of criminal offences, but the division between the two institutions was sometimes blurred.

${ }^{51}$ s.1, Reformatory and Industrial Schools Act 1891. The same power was provided for children detained in reformatory schools, but since these children had been convicted of a criminal offence, they not acceptable immigrants to the Canadian authorities, see Parker (2008).

52 s.58, Children Act 1908. s.21(6), Children Act 1908 also provided for the placement of a child where the person having care of them had been charged with abuse, and enabled the Secretary of State to empower the person having subsequent care of the child to procure their emigration.

${ }^{53}$ Home Office (1884).

${ }^{54}$ Parker (2008).

${ }^{55}$ Liverpool Catholic Children's Aid Committee Form of Application for Emigration of a Child. 364 NUG-14-6 Emigration Correspondence, Liverpool Record Office.
} 
children 'do not suffer any want of care'. ${ }^{56}$ The numbers of children emigrated were industrial schools: Boys: 109 Girls 55; and from reformatories: 29 Boys 1 Girl. The Royal Commission echoed the perception of emigration as an environment conducive to a child's welfare, stating that: 'Our belief is that, while all young emigrants have great chances of success, those whose surroundings in early life have not been normal, and whose environment has not been healthy, are likely to benefit to an especial degree by the freer life in the dominions. ${ }^{57}$

\section{Family Agency in Child Emigration}

The shift in the understanding of the nature of the child and the importance of the experience of childhood influenced the development of a range of measures aimed at addressing child welfare in the later nineteenth century, including the restriction of child employment, mandatory education, prevention of child cruelty and infant life protection. Whilst the state was increasingly intervening in the experience of childhood, charitable provision was central to the policing of the parental role and the expectations attached to it. By focusing on children regarded as neglected and deprived, not just orphans, charitable institutions sought to rescue their moral welfare. Dingwall, Eekelaar and Murray suggest that it is difficult to distinguish between the aim of rescuing the moral and spiritual welfare of the child from the concerns over the threat of criminality posed by disaffiliated young people. ${ }^{58}$ The judgment of these Victorian philanthropists were strongly shaped by middle class prejudices against the working poor, resulting in subjective assessments about character and morality, and risks of child criminality. ${ }^{59}$ In this section, the anxieties surrounding parenting in poor communities and the removal of parents from decision-making processes regarding child emigration will be further explored. Despite the marginal role of parents in the lives of children selected for emigration, some families demonstrated resilience and agency in attempting to regain influence and prevent the emigration of their child.

\section{Undermining Poor Parental Influence}

Emigration of a child would have a severe and permanent impact on the relationship between the child and their family. The means of communication from Canada were limited to letters; many children did not know of the whereabouts of their parents. In selecting emigration as a means of providing for the child's welfare, charities were making a deliberate choice regarding the effective severance of the relationship between the child and their family. Such arguments featured in the published reports of Liverpool's Catholic Father Berry Homes, the 1894 edition of which argued:

'Our criminals are bred in our streets ... an over-scrupulous regard for parental rights makes English lawgivers hesitate to act. ...In some cases boys who have come to us have been claimed by their parents, and have been forced by them, to

\footnotetext{
${ }^{56}$ Royal Commission (1917).

${ }^{57}$ Ibid.

${ }^{58}$ Dingwell (1984).

${ }^{59}$ Boucher (2014).
} 

arab. ${ }^{, 60}$

The belief that removing children from the bad influences of slums and family was good for them was central to decisions to emigrate children. Joy Parr argues that homes did their best to prevent parental visits and that '[e]migration was thus merely part of a system of kinship management. ${ }^{, 61}$

Murdoch has demonstrated that few children in charitable institutions or workhouses were in fact orphans: the majority had one parent, normally the mother still living. ${ }^{62}$ Poor families used institutional care as a form of support when economic or personal circumstances such as inability to find appropriate housing affected their ability to care for children. Institutional care was regarded, and used as, a temporary necessity by the poor. ${ }^{63}$ Few children were actually admitted to institutions as a result of parental abuse or neglect, despite the promotional literature and popular portrayal of the nature of admissions to charitable children's homes in particular. Murdoch found that parents were aware of their rights over their children and sought to maintain a relationship with them, particularly in relation to their medical care, religious teaching and any suggestions of abuse. ${ }^{64}$

As discussed above, when children were placed in both private philanthropic and state managed institutions, individual parents had far less scope for effectively objecting to the emigration of their child. For some parents, placement of a child in an institution with the prospect of emigration was of potential value in providing for a child that could not otherwise be maintained. ${ }^{65}$ However, the usually permanent breach in familial relationships made emigration an important form of disposal for charities where the parental influence was regarded as detrimental to the child. Moral authority was eventually reinforced by the legal authority to retain children from their parents' control, and was asserted over the child's welfare when the child was deemed an orphan, neglected or deserted by their parents. Judgment over the parenting of the child was therefore central to establishing control over the child and the decisionmaking power to emigrate the child without the parent's consent. Such agenda were based on negative views of poor parents, reinforced through policies and propaganda produced by childhood welfare organisations.

Assessments of the parenting of children emigrated by charities covered a range of behaviours. The 1888 Report on Miss Rye's Emigration Homes for Destitute Little Girls lists the circumstances in which the child found themselves prior to emigration, mediated by the charity. ${ }^{66}$ It includes orphans, but also those whose parents have been affected by financial, medical and social circumstances, and children who are no

\footnotetext{
${ }^{60}$ Father Berry's Homes, Pamphlet (1894-5), Liverpool Hope University Archives, IMG 8124/5.

${ }^{61}$ Parr (1994)

${ }^{62}$ Murdoch (2006).

${ }^{63}$ Ibid.

${ }^{64}$ Ibid.

${ }^{65}$ Boucher (2014).

${ }^{66}$ Liverpool University Archives, d630-1-1-17.
} 
longer wanted in the family home. There is evidence of outright abuse, such as: 'A.P. aged 17, father's address not known; mother a very bad woman who has threatened to kill the girl several times.' There are also cases where the child is not wanted by her parents, or where one parent had re-married: 'SC aged 15, father dead, mother married again and girl is not wanted at home.' The number of children could also affect the parents' ability to care for their children: 'CA aged 16, parents living but very poor with 9 other children to keep.' Then there are broad judgments regarding the behaviour of the individuals surrounding the child: 'AH aged 7, parents living but not fit to have care of child.' These judgments are also be more specific: 'EH aged 14, mother dead, father not in his right mind brought on by his bad life.' One theme that recurs is the child's wish to avoid an immoral life through emigration away from the influence of other relatives: 'EC aged 15, mother dead, girl has one sister doing very badly, and she does not want to follow her example.' This is particularly important in demonstrating the child's wish to be separated from bad influences. These descriptions were used in promotional material to highlight the work in protecting children, but also demonstrating the perceived justification for removing the child abroad from the influence of their circumstances, and resist criticisms of the practice arising immediately after the publication of the Doyle Report in 1875. Later private correspondence regarding the organisation of the emigration of children, demonstrate an assessment of risks posed to the child. Such judgments could be simple and direct, as demonstrated in 1903 by the Convent of the Golden Shepherd, a Catholic industrial school in Glasgow: 'Mary E Fleming was sent out from our school in December 1901 $\&$ is finally discharged. If the girl is with her parents in Liverpool we are afraid she is in danger. As to her willingness to go to Canada we are quite sure about that. ${ }^{67}$

Faith was an important marker of good parenting for evangelists, particularly Dr. Barnardo, the Church of England, but most notably for the Catholic Church. ${ }^{68}$ Spiritual welfare was the focus of assessments of suitability of emigration, rather than the capacity of parents or family to secure the child's welfare in a broader sense. In a letter regarding the payment of the costs for the emigration of two Catholic children from Liverpool in 1906, it was stated that: '...it was most advisable to emigrate from very bad surroundings which were a danger both to their faith and morals. ${ }^{\prime 69}$ The risk of loss of Catholic faith caused significant anxiety, as demonstrated by a lengthy letter regarding the emigration of ten boys in 1913 from Liverpool. The circumstances of each child were described, focusing on the circumstances for the current practice of their religion: 'I beg to inform you that we have a number of children in our Homes whose emigration to Canada is the only solution to their future welfare. We have gone through our lists and have selected ten boys whose emigration is absolutely necessary

\footnotetext{
${ }^{67}$ Letter from Convent of the Golden Shepherd to Liverpool Catholic Children's Aid Committee, $24^{\text {th }}$ April 1903, 364 NUG-14-6 Emigration Correspondence, Liverpool Record Office,.

${ }^{68}$ Boucher (2014).

${ }^{69} 26^{\text {th }}$ October 1906, 364 NUG-14-6, Liverpool Catholic Children's Aid Committee Emigration Correspondence Liverpool Record Office.
} 
in order to save them from the loss of their Faith. ${ }^{, 70}$ In the case of Percy Waterman, aged 9, the mother was said to be leading a 'bad life'. He was illegitimate and had been taken to Dr. Barnardo's Homes and transferred due to his religion. The report states that no enquiry had been made after him. The reference to the mother's failure to enquire after her child implies the child has been deserted and undermines any implied claim of the mother over her child.

Other cases demonstrated more specifically religious anxiety focusing on the child's spiritual health, rather than their physical well-being. Three brothers, Peter, Francis and Philip Griffin, were said to be in 'grave danger of being lost to the faith', given that their parents were both dead and their mother's relations were '... all Protestants of a hostile kind.' The children's grandfather was the next of kin, but given his age, the Catholic charity sought to emigrate the children before he died to prevent the situation where '...the Protestant Aunts will claim and even demand these children being handed over to them.' This form of assessment did not engage with the caring capacity of the aunts, or their relationship with the children, or the motivations of their Catholic grandfather. The focus on their religious identification undermined any familial claim to the children and justified their emigration to a Catholic placement in Canada.

Where parents had left their children in an institution, or the child had been removed there, undermining and labelling the relationship between the child and their family legitimised the removal of parental right and powers over their child and to consent to emigration. It created a narrative of necessity to intervene in the family to permanently ameliorate risks to the child. ${ }^{71}$ There is no doubt that some of the parents were behaving in a manner inimical to the welfare of their children. However, the assertion of moral authority over the child justified severing their relationship with their family through emigration to prevent the parental influence over the child. This was clearly regarded as being for the welfare of the child, but there was no consistent basis upon which to make an assessment. The subjective perception of the child's circumstances were coloured by the anxieties of the charitable institution, and loaded with preconceptions about childhood, and the child's spiritual welfare. The value of children's status in the family structure was coloured by economic considerations and value in their relationship with their parent or wider family disregarded.

Whilst the parental role in deciding to emigrate their child was progressively limited, the formal recording of consent by the child to emigration was maintained. Children selected for emigration by the poor law parish guardians were required to consent to emigration before the Justices at petty sessions, and the central government Poor Law Board also had to grant permission for the use of funds in this manner. ${ }^{72}$ For children emigrated from industrial schools, the child had to consent to emigration and the

\footnotetext{
$7010^{\text {th }}$ April 1913, 364 NUG-14-6, Liverpool Catholic Children's Aid Committee Emigration Correspondence Liverpool Record Office.

${ }^{71}$ Flegel (2007).

${ }^{72}$ s.4, Poor Law Amendment Act 1850.
} 
Secretary of State also had to grant permission. ${ }^{73}$ Children who were emigrated from was privately managed activity. The maintenance of the voice of the child in the state sanctioned process maintains respect for the child's capacity to make choices, particularly for older children. There is limited evidence of the child's understanding of the full implications of emigration, or of the extent to which the reality of their consent was tested by the Justices. On examining emigration lists, Parker found that children did refuse consent in some cases and were removed from the lists as a consequence, but questions whether the child truly had capacity to consent in this context. ${ }^{74}$ Emigration charities created extensive rhetoric around children who asked not to be returned to their parents because they recognised the risk to their own moral welfare. But the acceptance of the voice of the child in the process demonstrates that the child was regarded as having agency in the choices made over their welfare, even when the aim was to 'rescue' them from their circumstances.

\section{Family Agency in Emigration}

Despite the undermining of parental authority in emigration decisions, there is evidence that some parents and wider families sought to resist the emigration of their child, despite having been characterised as a poor influence in their children's lives. In doing so they demonstrated considerable resource in trying to prevent the emigration of the child concerned, and their objections had a wider influence on policy towards child emigration.

In 1910, the Home Office received an enquiry asking why a child, Grace Potts, had been emigrated to Canada without her father's consent. Letters were received from Mr J Hartley JP of Cockermouth, and Mr GA Arthur Esq., ${ }^{75}$ the father's employer. The child appeared to have been placed with in a Dr Barnardo's home under s.21(6), Children Act 1908 following a charge of cruelty. Under this section, the Secretary of State could empower the person or body having subsequent care of the child to procure their emigration. This had apparently occurred in the case of Grace Potts, although there was some uncertainty regarding whether the father had actually been convicted of cruelty, or whether Grace had been sent to the charitable home instead of being committed to an industrial school. The Home Office advised that Mr Hartley JP should be directed to s.21(6), Children Act 1908 and that the '...consent of the Secretary of State to emigration was given after consultation with the Justices and consideration of the circumstances under which the girl was committed to Dr Barnardo's care in the year 1908. ${ }^{76}$ In reply to this advice, ${ }^{77}$ Mr Hartley JP accepted the legality of the decision, but argued that the father should have been acquainted with the decision to emigrate his daughter by the Justices, and that the father was

\footnotetext{
${ }^{73}$ s.16, Industrial Schools Act 1861; subsequently s.70, Children Act 1908.

${ }^{74}$ Parker (2008).

${ }^{75}$ Letter from GA Arthur Esq. Cockermouth to Secretary of State for the Home Department, 6 May 1910, NA HO45 1059818863.

${ }^{76}$ NA HO45 1059818863.

${ }^{77}$ Letter from Mr Hartley JP, Amathwaite Hall, Cockermouth to Secretary of State for the Home Dept 25 May 1910, NA HO45 1059818863.
} 
most upset. Whilst the father may have been regarded as cruel or incapable of caring for his daughter, he still displays both an interest in her welfare and in the maintenance of his relationship with her. He managed to mobilise significant social relationships on his behalf to discover the reasons why he has not been told of the decision to emigrate Grace.

The case of Grace Potts encouraged the Home Office to change approach, suggesting that parents of children emigrated under s.21(6), Children Act 1908 should be heard before the decision was taken. It was stated that: 'The Justices who we consult ought really to make the inquiry but we cannot rely on their doing so. In this case, the child has gone (\& no doubt it is to her advantage to go) and all we can do is to answer Mr. Hartley's question... ' ${ }^{78}$ If the parent(s) consented to emigration, the Home Office anticipated that the Secretary of State would not then be consulted for his permission. If consent was refused, inquiries would be made by the police before the case was referred to the Secretary of State. In the context of s.21(6), Children Act 1908, this is an interesting decision, since the parent consulted may have been convicted of cruelty towards the child concerned and shows the uncertain status of the parent in relation to the child following conviction. The Home Office communicated with five emigration societies who sought to procure emigration in cases of child cruelty for their opinion on the approach proposed by the Home Office: NSPCC, Dr. Barnardo's Homes, Birmingham Children's Emigration Homes, Waifs and Strays Society, and the Catholic Emigration Association.

The NSPCC responded expressing concerns about the emigration of children if there was the potential for success at home. The Society was happy to comply with the suggested approach to notifying and seeking consent from parents before their child was emigrated, and sought to take great care in considering each suggestion for emigration. Robert Parr, the Director of the NSPCC, pointed out that '... the great reason for emigration is to remove a child from the bad influences of undesirable parents, and...we constantly find the desire on the part of the parent to secure the child for what can only be assumed to be improper motives. ${ }^{79}$ This theme was more strongly emphasised in the responses from Dr Barnardo's Homes and the Children's Emigration Homes in Birmingham. Mr W Baker, Honorary Director of Dr Barnardo's Homes replied arguing:

'The procedure now suggested will, I venture to submit, tend to make the emigration of such children more embarrassing and less successful than it has hitherto been, and may, in many cases, deprive children of the opportunity of being lifted entirely out of their former environment and given a chance of a fresh life, quite

\footnotetext{
${ }^{78}$ NA HO45 1059818863.

${ }^{79}$ Letter from Mr Robert Parr, Director of NSPCC to Under-Secretary of State for the Home Office, 22 June 2010, NA HO45 1059818863.
} 
removed from the possibility of coming again within the contaminating influences from which they have been rescued. ${ }^{80}$

The Under-Secretary of State made a note in the margin against this comment clarifying that, unless the parents present a proper reason for objecting to the emigration of the child, permission will still be granted by the Secretary of State. The concerns raised by Dr Barnardo's were echoed by the Birmingham Children's Emigration Homes, who also stated that they had not previously sought the Secretary of State's authorisation for children's emigration under s.21(6), Children Act 1908 if the parents had consented. ${ }^{81}$ The Home Office then sought advice from the NSPCC on the objections arising from Dr Barnardo's Homes. Robert Parr responded to suggest that there was always the potential for parental reform and that in these circumstances the child should be returned to their parents, and that recognition of parental rights would encourage their engagement. ${ }^{82}$

The objections of Grace Pott's father to her emigration to Canada did not change the status quo as regards the child, whose emigration had been achieved legally and was regarded positively. Mobilising the local JP and his employer did however result in a change of approach in policy regarding children emigrated under s.21(6), Children Act 1908. This change reflected existing practice regarding children emigrated from industrial schools and indicates that, whilst parents' opinion could be disregarded, it should not be completely dismissed. The anxieties expressed by Dr Barnardo's Homes and Birmingham Children's Emigration Homes concerning the control of parents over their children and the risks posed to the child by their parent resonated with the narrative surrounding emigration as a means of severing that influence. The attitude of the Director of the NSPCC was more nuanced, indicating a belief that parenting and the circumstances of the family that led to abuse, could change.

Grace Potts was followed by the case of Amelia Mason in 1914. Liverpool Girl's Industrial School sought to emigrate the 13-year-old girl to Canada having sought Amelia's consent and support from the Home Secretary under s.70, Children Act 1908. Complaints by the girl's father, extended family and his MP, Stephen Walsh, eventually persuaded the Home Secretary to stop the emigration. Amelia's father received notification of her proposed emigration from both the Liverpool Industrial School and the Director of Education for Liverpool.

[The] Committee have decided to apply to the Home Secretary for permission to emigrate the girl to Canada. Notice will be sent to you when the application is about to be sent off and it is open to you to send to the Home

\footnotetext{
${ }^{80}$ Letter from Mr W Baker, Honorary Director and Chairman of Council, Dr Barnardo's Homes to Home Office, 23 June 1910, NA HO45 1059818863.

${ }^{81}$ Letter from Mr George Jackson, Secretary to Children's Emigration Homes, St. Luke's Road, Birmingham to Home Office, 22 July 1910, NA HO45 1059818863.

${ }^{82}$ Letter from Mr Robert Parr, Director NSPCC to Under-Secretary of State for the Home Office, 7 July 1910, NA HO45 1059818863.
} 
Secretary any representations you desire to make against the emigration of this girl. $^{83}$

The forms sent by the school to the Home Office asked for the consent of the child, yet simultaneously privileged the institution's assessment of the parents. Amelia has formally consented to emigrating, but we cannot be sure how informed the child's consent was; given Amelia's age, education, and the fact she lived in the school, and taking into account the fact that she subsequently expressed a willingness to stay with family.

On receiving formal notification of the decision to emigrate Amelia, Mason sent a letter to the Secretary of State stating that 'I object very much', and emphasising that his married son Nathaniel could look after her instead. ${ }^{84}$ Yet the reformers had already made a judgement against Amelia's father. A report justifying Amelia's case for emigration by the Liverpool Girls' Industrial School to the Secretary of State deemed him 'Drunken, Worthless.' The report claimed both parents' fecklessness negated the need for their consent, stating that both parents were 'of drunken habits' and had been convicted of the criminal offence of 'child neglect. ${ }^{, 85}$ On $21^{\text {st }}$ May 1914, a Home Office memo argued that her industrial school was right to disregard the views of her father, noting:

'This is a case in which I am of opinion the parents' consent may be dispensed with. The father is a low black-guard, living apart from his family in common lodging-houses, is a drunkard and has been convicted 6 times for child neglect and drunkeness; the mother is also of drunken habits and has been convicted for neglecting her children, etc ... [the school is] acting wisely in the discretion conferred upon them by Section 70 of the Children Act. ${ }^{86}$

While this suggests that their opinion is based on law (such as the mention of convictions for 'child neglect'), elements of the judgment are purely personal; references to 'low blackguard', and 'common lodging houses' had no bearing on Mason's formal parental rights. Rather, the language drew on well-established narratives that emphasised the danger and lack of domesticity in a child's life, in order to justify their need to be rescued. There is also confusion of the grounds upon which a child has been committed to an institution, and the requirements before emigration can be secured. The policy of consulting with parents, even where the legislative provision authorising emigration did not require it, was undermined by the priority given to subjective assessments of parental circumstances. The evidential burden was placed on parents to prove the suitability of their parenting, otherwise their consent or refusal to emigration could be ignored. For all the bureaucratic engagement with the child's situation, the system of legislation and practice presumed heavily in favour of the emigrating institutions.

\footnotetext{
${ }^{83} 26^{\text {th }}$ March 1914, NA HO45-24661.

848 May 1914, NA HO45-24661.

$859^{\text {th }}$ May 1914 NA HO45-24661, IMG 9825-9828.

8621 May 1914, Minutes, NA HO45-24661, IMG_9822.
} 
Eekelaar highlights that little evidence remains of parental discontent with the

\footnotetext{
${ }^{87}$ Eekelaar (1994).

${ }^{88} 17^{\text {th }}$ June 1914 letter from N. Mason to Stephen Walsh, protesting the Home Sec's decision ('nothing short of tyranny') and lack of notice (2 days), and asking Walsh to bring the matter before Home Sec. IMG 9836; On 19 $9^{\text {th }}$ June 1914 the Home Sec wrote to Walsh, saying passage to Canada delayed for 'further inquiry' and produced a memo to the same effect. NA HO45-24661.

${ }^{89}$ NA HO45-24661.
} case demonstrates the importance of local networks of officials and police, whose support Edward Mason recruited, in offering avenues of resistance to emigration, as well as facilitating it in other cases. Edward and Nathaniel Mason's objections were promoted by the Labour MP Stephen Walsh, who had attended Kirkdale Industrial School as a child. ${ }^{88}$ Nathaniel Mason was Amelia's brother, who, having met the legal criteria to look after Amelia (with no previous convictions for neglect), expressed willingness to take Amelia on $22^{\text {nd }}$ May. However, the Home Secretary initially refused to stop the emigration, and only did so on $19^{\text {th }}$ June for 'further enquiry', apparently after the intervention of Walsh. Had the anti-emigration case not been persistently asserted by the Masons and Walsh, Amelia could easily have been emigrated. The Home Office only halted the emigration when evidence had been provided from the Chief Constable of Wigan, who sent a letter noting that Nathaniel was married, of 'good moral character' and abstinent from alcohol, and had a 'clean home' in a 'respectable neighbourhood.' ${ }^{89}$ In confirming this, the Chief Constable asserted that Nathaniel possessed the important qualities of masculine citizenship, including morality, self-control, and being able to provide a good home; thus aligning Nathaniel's character with middle-class ideals of respectability and challenging the image of fecklessness that the reformers relied upon in order to facilitate the emigration of children.

\section{Conclusions}

The history of child emigration demonstrates that the narrative around parenting and care for children can affect the legal protections of associated with the child and the meaning attached to the parent-child relationship. Parents still retained a stake in the decision to emigrate a child from state institutions, but their opinions were minimised or ignored based on perception of their circumstances. Charitable institutions were far more cavalier in seeking to avoid engagement with parents in pursuit of severing ties between the child and their family. Economic deprivation and the potential for exploitation of children in the industrialised cities, and the desire to promote religious identity fundamentally coloured the assessment of parental care. Whilst some parents were abusive of their children, the moral assertion of authority over the welfare of children was affected by the characterisation of the parent as having abandoned or deserted their child. Underlying expectations and perceptions can severely affect the decisions taken in relation to a particular child, which is an issue for vigilance in the operation of the modern child protection system. 
Charities seeking the emigration of children were seeking to pursue what they regarded as the child's welfare, but there is evidence that parents also cared about their children. Placement in a children's home was not always intended to sever their relationship with their child in the way that child emigration achieved. Without a clear framework for analysing whether a decision secured a child's interests and relationship with their family, the decision-making process embodied subjectivity and open-textured assessments. Yet, despite the legal and moral authority carried by state institutions and charity, there is evidence of parents and families resisting the narrative and attempting to retrieve the child or prevent their emigration in the first place. The pursuit of legal complaints against charitable institutions, or informal complaints through other channels to the Home Office provided parents with a route for some redress, or at least explanation of the decision to emigrate their child. Considering this agency exhibits the importance of considering the voice of the parents and the wider family in the care of their child, even when the relationship with their child has been affected or undermined by circumstances or even neglect.

\section{References}

Barnardo, Thomas. (1885). Is Philanthropic Abduction Ever Justified?. Night and Day: A Monthly Record of Christian Missions and Practical Philanthropy 98.

Boucher, Ellen. 2014. Empire's Children: Child Emigration, Welfare and the Decline of the British World 1869-1967. Cambridge: Cambridge University Press.

Dingwell, Robert, et al. 1984. Childhood as a social problem: A survey of the history of legal regulation. Journal of Law and Society 11: 207-232.

Doyle Report. 1875. Report to the President of the Local Government Board as to the Emigration of Pauper Children to Canada, British Parliamentary Papers, HC 9.

Eekelaar, John, et al. 1982. Victims or Threats? Children in Care Proceedings. The Journal of Social Welfare and Family Law 4: 68-82.

Eekelaar, John. 1994. The Chief Glory: The export of children from the United Kingdom. Journal of Law and Society 21: 487-504.

Flegel, Monica. 2007. Facts and their Meaning: Child protection, intervention, and the National Society for the Prevention of Cruelty to Children in Late NineteenthCentury. Victorian Review 33: 87-101.

Frost, Ginger. 2013. Under the Guardian's Supervision: Illegitimacy, Family and the English Poor Law 1870-1930. Journal of Family History 38: 122-139.

Godfrey, Barry et al. 2017. Young Criminal Lives: Life Courses and Life Chances from 1850. Oxford: Oxford University Press.

Haines, Robin. 1997. 'The idle and the drunkard won't do there': Poverty, the new poor law and nineteenth century government assisted emigration to Australia from the United Kingdom. Australian Historical Studies 27: 1-21. 
Home Office (1884). Report of the Royal Commission on Reformatory and Industrial Schools. C ( $2^{\text {nd }}$ series $), 3876$.

Howells, Gary. 2000. Emigration and the Poor Law: The Norfolk Emigration Fever of 1836. Rural History 11: 145-164.

Moss, Eloise, et al. 2017. Rethinking Child Welfare and Emigration Institutions, 1870-1914. Cultural and Social History Journal 14: 647-668.

Murdoch, Lydia. 2006. Imagined Orphans: Poor Families, Child Welfare and

Contested Citizenship in London. New Brunswick: Rutgers University Press.

Parr, Joy. 1994. Labouring Children: British Immigrant Apprentices to Canada 18691924. Toronto: University of Toronto Press.

Parker, Roy. 2008. Uprooted: The Shipment of Poor Children to Canada 1867-1917. Bristol: Policy Press.

Richards, Eric. 2004. Britannia's Children: Emigration from England, Scotland, Wales and Ireland since 1600. London: Hambledon.

Royal Commission (1917). Final Report on the Natural Resources, Trade and Legislation of certain portions of His Majesty's Dominions. Cd.8462. 